\title{
Optimal monetary policies and policy interdependence in the world economy
}

\author{
Kent P. Kimbrough* \\ Department of Economics, Duke University, Durham, NC 27706, USA
}

\begin{abstract}
The literature on strategic policy interactions has focused on the implications of alternative strategic policy interactions, cooperative versus noncooperative, for equilibrium macroeconomic policies given the state of the world economy. This paper asks how changes in world economic conditions alter equilibrium policies given the nature of policy interdependence among nations. The paper considers a world economy comprised of two countries operating under a system of flexible exchange rates. Both governments act noncooperatively and choose the rate of growth of their money supply so as to maximize the utility of their country's residents given the rate of growth of the other country's money supply. The resulting Nash equilibrium rates of growth of the home and foreign money supplies are determined and the dependence of international differences in money growth and inflation rates on international differences in technology. (JEL E52, E60, F41, F42).
\end{abstract}

The international transmission of monetary and fiscal policies has been studied a great deal by economists. However, policy interdependence, how one country's policies depend on the policies enacted by other countries, has only recently begun to be explored. Hamada's (1976) paper was one of the first major contributions in this regard. Hamada considered a world economy comprised of $n$ countries operating under a fixed exchange rate system in which policymakers set domestic credit growth so as to maximize an objective function depending on inflation and the rate of accumulation of international reserves. Using this framework Hamada demonstrated that, in equilibrium, optimal domestic credit policies are generally not Pareto efficient when they are chosen noncooperatively but are Pareto efficient when they are set cooperatively. In subsequent work, Hamada $(1979,1985)$ has elaborated on this and various other aspects of cooperative and noncooperative monetary policies under both fixed and flexible exchange rates.

Many others have followed Hamada's lead by comparing the properties of coopcrative and noncooperative monetary policies. Eichengreen (1985), for instance, considers discount rates as the instrument of monetary policy and examines issues of leadership and cooperation during the interwar years under the gold standard. Oudiz and Sachs (1985) have used simulation methods to

\footnotetext{
* I would like to thank Grant Gardner and two anonymous referees for their comments. Funding for this research was provided in part by a grant from the Sloan Foundation to the Department of Economics.
} 
quantify the gains from monetary policy coordination under flexible exchange rates. Rogoff (1985) questions the widely accepted viewpoint that there are gains to coordinating monetary policies by providing an example in which welfare may be lower in the coooperative equilibrium than in the noncooperative equilibrium.

Even more recently, attention has been focused on the issue of the international coordination of fiscal policies. Kehoe (1987) considers a situation in which governments choose time profiles for tax rates on wages in order to maximize some weighted average of the utilities of current and future generations and considers the interactions between country size and policy coordination. Chari and Kehoe (1990) further explore these issues. Turnovsky (1988) compares cooperative and noncooperative government spending policies and shows that the noncooperative equilibrium tends to be characterized by higher government spending on import goods than the cooperative equilibrium. Devereux (1990) considers how the welfare properties of cooperative and noncooperative fiscal policies depend on the ability of governments to precommit to a given policy. That is, he explores the interactions between policy cooperation and time consistency. Kehoe (1989) provides an example in which noncooperative fiscal policies yield higher welfare than cooperative fiscal policies. His results help to clarify certain aspects of Rogoff's earlier work on monetary policy.

Recent work grounded in intertemporal optimization and dealing with strategic macroeconomic policy interactions in the world economy characterizes and compares the properties of cooperative and noncooperative policies. However, the design of macroeconomic policies depends not only on these strategic interactions but also on underlying economic conditions. For instance, given other countries' policies, unanticipated changes in tastes and technology will alter the macroeconomic policies of all countries in the world economy due to economic interdependence among them. As a result of policy interdependence, these initial policy changes will give rise to additional shifts in monetary and fiscal policies until a new equilibrium set of policies is attained. The optimizing literature on strategic policy interactions has focused on the latter issue only: what are the implications of alternative strategic policy interactions, cooperative versus noncooperative, for equilibrium macroeconomic policies given the state of the world economy? This paper asks how changes in world economic conditions alter equilibrium policies given the nature of policy interdependence among nations. ${ }^{1}$

The paper considers a world economy comprised of two countries operating under a system of flexible exchange rates. Both governments act noncooperatively and choose the rate of growth of their money supply so as to maximize the utility of their country's residents given the rate of growth of the other country's money supply. The resulting Nash equilibrium rates of growth of the home and foreign money supplies are determined and their response to changes in tastes, technology, and exogenously-given fiscal policies are considered. It is shown that countries with superior technology will generally have lower inflation rates.

The underlying model of the world economy is an extension of Dornbusch et al.'s (1977) Ricardian model with a continuum of goods. The extensions involve adding variable labor supplies and introducing money via a cash-in-advance constraint as in Helpman (1981). In such an environment, the Nash equilibrium money supply growth rates pin down national inflation rates and changes in monetary policy influence real activity and private sector utility through an inflation tax channel as in Aschauer and Greenwood (1983), Stockman (1985) 
and Kimbrough $(1986,1991)$. The setup is thus sufficient to allow monetary policy changes to have real effects and for monetary policy formation to be examined in an optimizing framework. The combination of a variable labor supply and a conlinuum of goods allows changes in money growth rates to alter real activity at both intensive and extensive margins. At the intensive margin changes in money growth rates alter labor efforts at home and abroad. These changes in turn affect the terms of trade and alter the range of goods produced by each country. That is, at the extensive margin monetary policy shifts influence international patterns of trade and specialization. The impact of monetary policy on the international pattern of trade and specialization, the extensive margin, is an important ingredient in determining the response of Nash equilibrium policies to changes in world economic conditions. ${ }^{2}$

\section{The world economic environment}

The world economy is comprised of two countries with Ricardian production technologies. In both countries a representative consumer allocates labor effort to produce a subset of goods from the feasible set of goods which is a continuum indexed over the unit interval $[0,1]$.

The subset of goods each country produces is determined by comparative advantage. A key determinant of comparative advantage is the international pattern of relative unit labor requirements which, following Dornbusch et al. (1977), is summarized by

$$
A(z)=a^{*}(z) / a(z), \quad A^{\prime}(z)<0,
$$

where $a(z)$ is the labor required to produce a unit of good $z$ in the home country and asterisks denote foreign variables.

Although labor is mobile across sectors within each country it is not internationally mobile. Wages are thus equalized across sectors within a country but not across countries. As a result, good $z$ is produced at home only if the average cost of production is lower at home than it is abroad. This requires that $W_{t} a(z) \leqslant e_{t} W_{t}^{*} a^{*}(z)$, where $W_{t}\left(W_{t}^{*}\right)$ is the nominal wage at home (abroad) in terms of the home (foreign) currency and $e_{t}$ is the exchange rate. That is, good $z$ is produced at home provided that

$$
\omega_{t} \leqslant A(z)
$$

where $\omega_{t}=W_{t} / e_{t} W_{t}^{*}$ is the 'double factoral' terms of trade or, more simply, the wage ratio.

Consumers at home and abroad have identical time-separable preferences over goods and leisure. The lifetime utility of the representative home consumer is given by

$$
\sum_{t=0}^{\infty} \beta^{t} U\left[c_{t}-g\left(\ell_{t}\right)\right],
$$

where $c_{t}$ is composite consumption, $\ell_{t}=\int \ell_{t}(z) d z$ is home labor supply at time $t$, and $0<\beta<1$ is the subjective discount factor.

The within-period utility function $U[\cdot]$ exhibits positive and diminishing marginal utility. Composite consumption is a Cobb-Douglas function of the consumption of individual goods $c_{t}(z)$ over the unit interval $[0,1]$ and is given 
by $c_{t}=\exp \left\{\int b(z)\left[\ell n c_{t}(z)-\ell n b(z)\right] d z\right\}$, where $\int b(z) d z=1$. The disutility of labor effort $g(\cdot)$ is given by $g\left(\ell_{t}\right) \equiv \ell_{t}^{1+(1 / \eta)} /[1+(1 / \eta)], \eta>0$.

In addition to choosing time profiles for consumption and labor supply, consumers also must choose time profiles for money and bonds denominated in the home and foreign currencies. Domestic and foreign currency bonds, domestic holdings of which are denoted $b_{t}^{h}$ and $b_{t}^{* h}$, offer nominal interest rates of $R_{\mathrm{t}}$ and $R_{t}^{*}$. Money is held because goods purchases are subject to cash-in-advance constraints which require that goods be purchased using the seller's currency. Given positive nominal interest rates, consumers will never use money as a store of value since it is rate-of-return dominated by bonds.

The representative home consumer's problem is thus to choose time profiles for the consumption of each good, labor supply, bond holdings, and money holdings so as to maximize $\langle 3\rangle$ subject to the sequence of constraints

$$
\begin{gathered}
b_{t}^{h}+e_{t} b_{t}^{* h}+M_{t}^{h}+e_{t} M_{t}^{* h}=W_{t-1} \ell_{t-1}+\tau_{t}+\left(1+R_{t-1}\right) b_{t-1}^{h}+e_{t}\left(1+R_{t-1}^{*}\right) b_{t-1}^{*}, \\
\int P_{t}(z) c_{h t}(z) d z=M_{t}^{h}, \\
\int P_{t}^{*}(z) c_{f t}(z) d z=M_{t}^{* h},
\end{gathered}
$$

for $t=0,1,2, \ldots$, where $M_{t}^{h}\left(M_{t}^{* h}\right)$ represents domestic holdings of domestic (foreign) money, $\tau_{t}$ is a lump-sum transfer, $c_{h t}(z)\left[c_{f t}(z)\right]$ denotes domestic purchases of domestic (foreign) goods, and $P_{t}(z)\left[P_{t}^{*}(z)\right]$ is the domestic (foreign) currency price of good $z$.

The constraints (4)-(6) can be combined into the single constraint

$$
\langle 7\rangle \int P_{t}(z) c_{t}(z) d z=W_{t-1} \ell_{t-1}+\tau_{t}+\left(1+R_{t-1}\right) b_{t-1}^{h}+e_{t}\left(1+R_{t-1}^{*}\right) b_{t-1}^{* h}-b_{t}^{h}-e_{t} b_{t}^{* h} \text {, }
$$

which must hold for $t=0,1,2, \ldots$. The home consumer's problem is thus to maximize $\langle 3\rangle$ subject to the sequence of budget constraints $\langle 7\rangle$.

The consumption of individual goods in each period is chosen to maximize real consumption subject to the sequence of budget constraints $\int P_{t}(z) c_{t}(z) d z=C_{t}$ where $C_{t}$ is an exogenously-given level of nominal spending each period. Given the Cobb-Douglas nature of the consumption composite, the solution to the first-stage problem yields the demand functions

$$
c_{t}(z)=b(z) C_{t} / P_{t}(z)
$$

for $t=0,1,2, \ldots$.

The consumer's second-stage problem is to allocate nominal spending intertemporally and to choose time profiles for labor supply and bond holdings so as to maximize $\langle 3\rangle$ subject to $\langle 7\rangle$. (Money holdings are then determined residually via the binding cash-in-advance constraints.) The solution to this problem is facilitated by noting that the first-stage problem implies that real consumption satisfies the condition $c_{t}=C_{t} / P_{t}$ where the period $t$ price level is defined by $\ell n P_{t}=\int b(z) \ell n P_{t}(z) d z$.

The solution to the consumer's second stage problem implies that, in equilibrium if both domestic and foreign bonds are held, the interest rate parity condition

$$
1+R_{t}=\varepsilon_{t}\left(1+R_{t}^{*}\right)
$$

holds in all periods, where $\varepsilon_{t} \equiv e_{t+1} / e_{t}$ is the gross rate of depreciation of the home currency. It also implies that the home country labor supply function for 
each period is

$$
\ell_{t}=\left[W_{t} / P_{t}\left(1+R_{t}\right)\right]^{\eta}
$$

The parameter $\eta$ is thus the elasticity of the labor supply curve.

The assumption that tastes are the same at home and abroad means that the preference parameters $\beta, b(z)$, and $\eta$ are the same in the two countries. Foreign utility, of course, depends on foreign consumption, $c_{t}^{*}$, and foreign labor supply, $\ell_{t}^{*}$. The foreign country demand functions and labor supply functions are thus similar to $\langle 8\rangle$ and $\langle 10\rangle$. However, since foreigners are paid in foreign currency for their labor effort, it is the foreign nominal interest rate that is relevant for the foreign inflation tax on labor supply.

\section{Equilibrium in the world economy}

The exchange rate is taken to be flexible and it is assumed that the governments of both countries can make binding policy commitments. Government policy in each country is limited to printing up money in order to finance transfer payments. These transfer payments must satisfy the budget constraints $\tau_{t}=\left(\mu_{t}-1\right) M_{t-1}$ and $\tau_{t}^{*}=\left(\mu_{t}^{*}-1\right) M_{t-1}^{*}$, where $M_{t}\left(M_{t}^{*}\right)$ is the domestic (foreign) money supply at time $t$ and $\mu_{t}\left(\mu_{t}^{*}\right)$ is the gross rate of growth of the domestic (foreign) money supply.

There are no barriers to trade so goods market arbitrage assures that

$$
P_{t}(z)=\epsilon_{t} P_{t}^{*}(z)
$$

Since tastes are identical in the two countries and all goods are traded, the goods market arbitrage conditions also assure that purchasing power parity holds so that $P_{t}=e_{t} P_{t}^{*}$ in all periods.

There are no regular, anticipated changes in tastes or technology so in equilibrium it will be optimal for both countries to adopt a constant money growth rate. The equilibrium for the world economy is thus a steady-state equilibrium that is instantaneously attained following any unanticipated shocks. Consumption and labor profiles in both countries are flat. Abstracting from any initial debt, this means that equilibrium consumption levels at home and abroad must satisfy $c=w \ell$ and $c^{*}=w^{*} \ell^{*}$, where time subscripts on real variables are now omitted due to the steady-state properties of the equilibrium and $w \equiv W_{t} / P_{t}$ $\left(w^{*} \equiv W_{t}^{*} / P_{t}^{*}\right)$ is the pre-tax real wage in the home (foreign) country.

Equilibrium requires that goods and money markets clear. Goods market equilibrium holds when $c_{h}(z)+c_{h}^{*}(z)=y(z)$ and $c_{f}(z)+c_{f}^{*}(z)=y^{*}(z)$ for all $z$ where $y(z)\left[y^{*}(z)\right]$ is the home (foreign) country's output of good $z$. In conjunction with the cash-in-advance constraints $\langle 5\rangle$ and $\langle 6\rangle$ plus their foreign analogs, these goods market equilibrium conditions can be used to show that money market equilibrium obtains when $M_{t}=\int P_{t}(z) y(z) d z$ and $M_{t}^{*}=\int P_{t}^{*}(z) y^{*}(z) d z$. However, since labor is the only factor of production, nominal output in each country equals pre-tax nominal wage payments. Hence the conditions for money market equilibrium can be written as

$$
M_{t}=W_{t} \ell \quad \text { and } \quad M_{t}^{*}=W_{t}^{*} \ell^{*} .
$$

Since pre-tax real wages and labor effort in both countries are constant in equilibrium, it follows from $\langle 12\rangle$ that inflation rates at home and abroad are constant at $\mu-1$ and $\mu^{*}-1$. From the Fisher equations, nominal interest rates 
are constant at

$$
1+R=\mu(1+r) \quad \text { and } \quad 1+R^{*}=\mu^{*}(1+r),
$$

where the world real interest rate is constant at $r=\beta^{-1}-1$. Given that the equilibrium world real interest rate is constant, the home and foreign inflation tax factors, $R /(1+R)$ and $R^{*} /\left(1+R^{*}\right)$, are directly related to home and foreign money supply growth rates. It is also worth noting that, since the interest rate parity condition $\langle 9\rangle$ is satisfied, $\langle 13\rangle$ implies that the equilibrium rate of depreciation of the home currency is

$$
\varepsilon=\mu / \mu^{*} \text {. }
$$

Since equilibrium nominal interest rates are directly related to money growth rates, it follows immediately from $\langle 14\rangle$ that the rate of depreciation, $\varepsilon$, provides a measure of the inflation tax rate in the home country relative to that abroad. The greater the rate of depreciation of the home currency the relatively higher the home country's inflation tax is compared to that of the foreign country.

It was pointed out before that the equilibrium pattern of specialization is determined by comparative advantage as summarized by $\langle 2\rangle$. Given the wage ratio $\omega$, there is some critical good $\tilde{z}$ which satisfies the condition

$$
\omega=A(\tilde{z})
$$

and production according to comparative advantage implies that the home country produces goods in the range $[0, \tilde{z}]$ and the foreign country produces goods in the range $[\tilde{z}, 1]$. The technological relationship $\langle 15\rangle$ is depicted in Figure 1 . For any given wage ratio the home country produces all goods to the left of the $A(z)$ schedule and the foreign country produces all goods to the right.

The equilibrium wage ratio and pattern of specialization must also clear the home and foreign labor markets. Given the international pattern of specialization, the share of world spending that falls on domestically produced goods is

$$
\theta(\tilde{z}) \equiv \int_{0}^{\tilde{z}} b(z) d z, \quad \theta^{\prime}(\tilde{z})>0 .
$$

Labor market equilibrium thus requires that $W_{t} \ell=\theta(\tilde{z})\left(W_{t} \ell+e_{t} W_{t}^{*} \ell^{*}\right)$, where the term on the right is the derived demand for domestic labor in nominal terms. Using the labor supply function $\langle 10\rangle$ and its foreign counterpart, the definition of the wage ratio, the interest rate parity condition $\langle 13\rangle$, and the purchasing power parity condition, $P_{t}=e_{t} P_{t}^{*}$, the labor market equilibrium condition can be rearranged as

$$
\omega=B(\tilde{\mathrm{z}}, \varepsilon) \equiv\{\theta(\tilde{z}) /[1-\theta(\tilde{z})]\}^{1 /(1+\eta)} \varepsilon^{\eta /(1+\eta)},
$$

where $B_{z}=(1+\eta)^{-1}\left[\theta^{\prime} /(1-\theta)^{2}\right]\left(\ell^{*} / \ell\right)>0, B_{\varepsilon}=[\eta /(1+\eta)](\omega / \varepsilon)>0$.

The labor market equilibrium schedule $\langle 16\rangle$ is shown in Figure 1 for a given rate of depreciation $\varepsilon_{0}=\mu_{0} / \mu_{0}^{*}$. Since $B_{z}>0$, the schedule is upward sloping. Intuitively, an increase in the range of goods produced at home tends to create an excess demand for domestic labor, in relative terms, and hence must be accompanied by an increase in the wage ratio to maintain labor market equilibrium. The rise in the wage ratio restores equilibrium through two distinct channels. First, it raises the relative price of domestically produced goods and chokes off some of the excess demand for labor associated with an increase in 


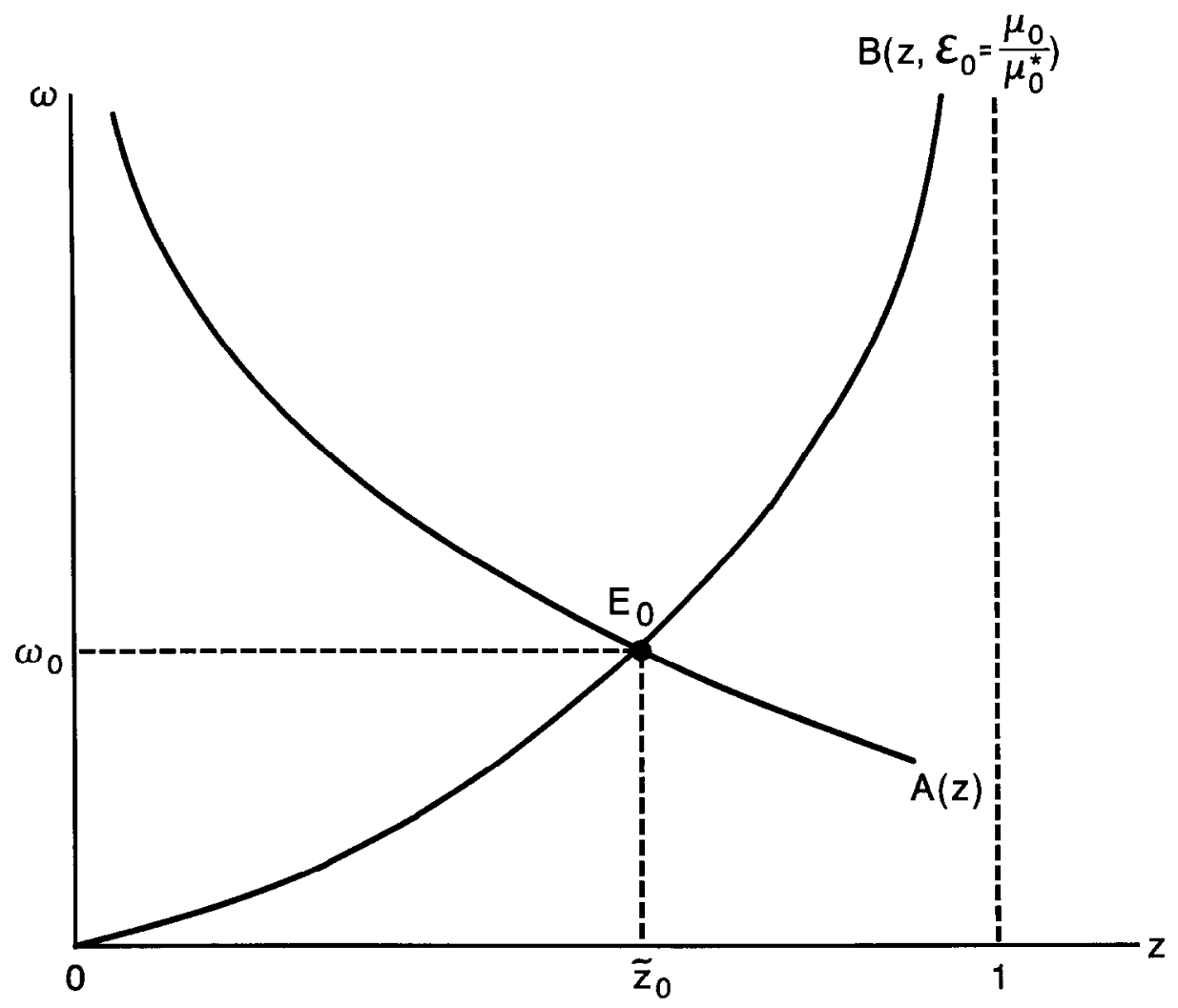

FIGURE 1.

the range of goods produced domestically. Second, the increase in the wage ratio stimulates the domestic supply of labor relative to the foreign supply of labor. To see this formally, divide foreign labor supply by $\langle 10\rangle$ and use the interest rate parity and purchasing power parity conditions to obtain

$$
\ell^{*} / \ell=(\varepsilon / \omega)^{\eta} .
$$

If the elasticity of labor supply, $\eta$, were zero, the labor market equilibrium schedule would be identical to that of Dornbusch et al. (1977) who abstract from changes in relative labor supplies in response to changes in the wage ratio.

Combining the labor market equilibrium condition $\langle 16\rangle$ with the fact that the international pattern of specialization depends on comparative advantage as described by $\langle 15\rangle$, it follows that the marginal good $\tilde{z}$ that pins down the international allocation of production is implicitly determined by the condition

$$
A(\tilde{z})=B(\tilde{z}, \varepsilon) \text {. }
$$

The resulting equilibrium is at point $E_{0}$ in Figure 1 . The equilibrium wage ratio is $\omega_{0}$, the home country produces goods in the range $\left[0, \tilde{z}_{0}\right]$, and the foreign country produces goods in the range $\left[\tilde{z}_{0}, 1\right]$. 


\section{The effects of changes in money supply growth rates}

Suppose that initially the world economy is in equilibrium at point $E_{0}$ in Figure 2 and that the home country increases its money growth rate from $\mu_{0}$ to $\mu_{1}$. As can be seen from $\langle 14\rangle$, this raises the rate of depreciation of the home currency from $\varepsilon_{0}=\mu_{0} / \mu_{0}^{*}$ to $\varepsilon_{1}=\mu_{1} / \mu_{0}^{*}$. The result is that the labor market equilibrium schedule shifts upward by $[\eta /(1+\eta)] \hat{\varepsilon}=[\eta /(1+\eta)] \hat{\mu}$, where a circumflex over a variable denotes its percentage change $(e . g . \hat{\mu}=d \mu / \mu)$. This upward shift of the labor market equilibrium schedule is shown in Figure 2.

That is, given the initial equilibrium wage ratio and pattern of specialization, $\omega_{0}$ and $\tilde{z}_{0}$, the increased rate of growth of the home money supply, by raising the home country's inflation tax rate and discouraging labor effort, creates an excess demand for domestic labor. In order to maintain equilibrium, wage ratio must rise and the range of goods produced domestically must contract. The new equilibrium for the world economy is at point $E_{1}$ in Figure 2 with a wage ratio of ()$_{1}$ and the international pattern of specialization now being characterized by the marginal good $\tilde{z}_{1}$.

Formally, it can be shown from $\langle 18\rangle$ that $d \tilde{z} / d \varepsilon=-B_{\varepsilon} /\left(B_{z}-A_{z}\right)<0$ which, along with $\langle 16\rangle$, implies that

$$
\hat{\omega}=\frac{\eta}{1+\eta} \times \frac{A_{z}}{A_{z}-B_{z}} \times\left(\hat{\mu}-\hat{\mu}^{*}\right),
$$

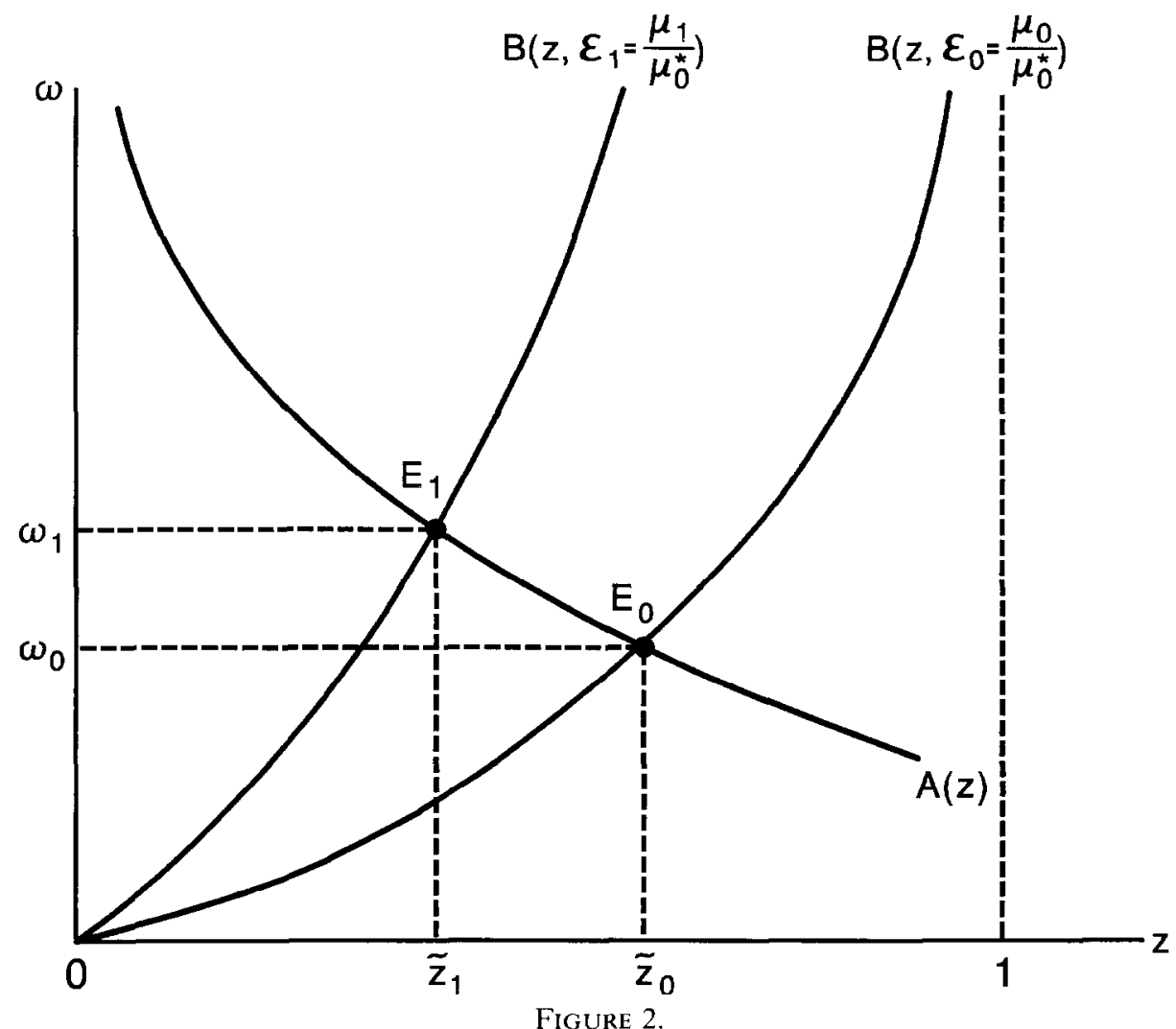

Figure 2. 
where use has been made of the fact that from $\langle 14\rangle \hat{\varepsilon}=\hat{\mu}-\hat{\mu}^{*}$. From $\langle 19\rangle$, it is apparent that the equilibrium wage ratio increases by a smaller proportion than the increase in the domestic money growth rate. In addition, it follows directly from $\langle 17\rangle$ and $\langle 19\rangle$ that an increase in the domestic money growth rate reduces the relative supply of domestic labor since

$$
\hat{\ell}^{*}-\hat{\ell}=\eta \times\left\{1-[\eta /(1+\eta)]\left[A_{z} /\left(A_{z}-B_{z}\right)\right] \times\left(\hat{\mu}-\hat{\mu}^{*}\right) .\right.
$$

These results indicate that an increase in the home country's money supply growth rate raises the equilibrium wage ratio and leads to a decline in output and employment at home relative to output and employment abroad. However, in order to assess the welfare effects of changes in money supply growth rates, it is necessary to pin down the effects of such changes on the levels of real wages and employment at home and abroad. With this in mind, note that an increase in the rate of growth of the home money supply does not alter the foreign inflation tax since, from $\langle 13\rangle$, the foreign nominal interest rate continues to be given by $1+R^{*}=\mu_{0}^{*}(1+r)$ and the real interest rate is unchanged since the world economy's equilibrium is a steady state. As a result, foreign labor supply rises or falls as the foreign real wage, $w^{*} \equiv W^{*} / P^{*}$, rises or falls.

Since the world economy is in a steady-state equilibrium, immediately following an increase in the rate of growth of the home money supply the rate of change of the foreign country's nominal wage rate and price level remain constant at $\mu_{0}^{*}$. Any change in the foreign real wage in response to an increase in the domestic money growth rate is thus accomplished by one-time jumps in the foreign nominal wage rate and price level at the time of the increase. Letting $\hat{W}^{*}$ and $\hat{P}^{*}(z)$ denote these one-time jumps in foreign wages and prices, it follows from the definition of the foreign price level that

$$
\hat{w}^{*}=\hat{W}^{*}-\int b(z) \hat{P}^{*}(z) d z .
$$

The change in foreign goods prices differs across goods in the following way. Goods in the interval $\left[0, \tilde{z}_{1}\right]$ are produced in the home country before and after the increase in the domestic money supply growth rate. From the goods market arbitrage condition $\langle 11\rangle$ and average cost pricing, it follows that the foreign currency price of these goods is $P_{t}^{*}=W_{t} a(z) / e_{t}=W_{t}^{*} \omega \mathrm{ra}(z)$. Therefore, $\hat{P}^{*}(z)=\hat{W}^{*}+\hat{\omega}$ for $z \in\left[0, \tilde{z}_{1}\right]$.

Goods in the interval $\left[\tilde{z}_{0}, 1\right]$ are produced in the foreign country before and after the policy change so that $P_{t}^{*}(z)=W_{t}^{*} a^{*}(z)$ for these goods and thus $\hat{P}^{*}(z)=\hat{W}^{*}$ for $z \in\left[\tilde{z}_{0}, 1\right]$.

The production of goods in the interval $\left[\tilde{z}_{1}, \tilde{z}_{0}\right]$ shifts from the home country to the foreign country when the home money growth rate is increased. The foreign currency price of these goods is thus $P_{t}^{*}(z)=W_{t}^{*} a^{*}(z) D(z)$, where $D(z)=\omega_{0} / A(z)$ before the policy change and $D(z)=1$ after the policy change. Therefore, $\hat{P}^{*}(z)=\hat{W}^{*}+\hat{D}(z)$ for $z \in\left[\tilde{z}_{1}, \tilde{z}_{0}\right]$, where $0 \leqslant \hat{D}(z)=\left[A(z)-\omega_{0}\right] / \omega_{0} \leqslant \hat{\omega}$, $\partial \hat{D}(z) / \partial z<0$. The $\hat{D}(z)$ function reflects the impact of the change in the country that has a comparative advantage in producing good $z$ on the price of good $z$. Technology considerations thus matter for the change in the prices of these goods. Note that $\hat{D}\left(\tilde{z}_{1}\right)=\hat{\omega}$ since $\tilde{z}_{1}$ is in the domestic production set before the policy change and is the marginal good after the policy change so that $\hat{P}^{*}\left(\tilde{z}_{1}\right)=\widehat{W}^{*}+\hat{\omega}$. Similar considerations imply that $\hat{D}\left(\tilde{z}_{0}\right)=0$.

Using these results for changes in the foreign currency prices of goods in $\langle 20\rangle$, 
it can be seen that the change in the foreign real wage in response to an increase in the rate of growth of the home money supply is

$$
\hat{w}^{*}=-\theta\left(\tilde{z}_{1}\right) \hat{\omega}-\int_{\tilde{z}_{1}}^{\tilde{z}_{11}} b(z) \hat{D}(z) d z<0 .
$$

That is, an increase in the rate of growth of the domestic money supply reduces the foreign real wage. Note that $\left|\hat{w}^{*}\right|<\hat{\omega}$ since $\theta\left(\tilde{z}_{1}\right)<1$ and $0<\hat{D}(z)<\hat{\omega}$.

The change in the domestic real wage is

$$
\hat{w}=\hat{\omega}+\hat{w}^{*}=\left[1-\theta\left(\tilde{z}_{1}\right)\right] \hat{\omega}-\int_{\sum_{1}}^{\tilde{z}_{0}} b(z) \hat{D}(z) d z>0 .
$$

The domestic real wage must rise because the fall in the foreign real wage is less than the rise in the wage ratio. Further the domestic after-tax real wage, $w /(1+R)$, falls since, using $\langle 13\rangle$, its percentage change is given by $\hat{w}-\hat{\mu}$ and, as is evident from the expression for $\hat{w}$, the domestic real wage rises by less than the proportionate change in the domestic nominal interest rate.

These results imply that an increase in the rate of growth of the domestic money supply reduces after-tax real wages at home and abroad. This, of course, means that an increase in the rate of growth of the domestic money supply also reduces employment in both countries. Intuitively, trade in goods is a partial substitute for international labor mobility and thus the burden of a rise in the inflation tax in one country is spread throughout the world economy. However, the foreign after-tax real wage falls by $\hat{w}^{*}$ while the after-tax real wage at home falls by $\hat{w}-\hat{\mu}=\hat{w}^{*}+(\hat{\omega}-\hat{\mu})<\hat{w}^{*}$. That is, although the burden of an increased domestic inflation tax is spread internationally via trade in goods, its effects, on both real wages and employment, are nonetheless felt more strongly in the home country.

The results just outlined for the real wage and employment effects of changes in the rate of growth of the domestic money supply apply in a symmetric fashion to changes in the rate of growth of the foreign money supply. These results are conveniently summarized by the following equilibrium real wage and employment functions:

$$
\begin{aligned}
& w=w\left(\mu, \mu^{*}\right), \\
& w_{\mu}>0>w_{\mu^{*}} \\
& \ell=\ell\left(\mu, \mu^{*}\right), \quad \ell_{\mu}, \ell_{\mu^{*}}<0, \\
& \langle 22\rangle w^{*}=w^{*}\left(\mu, \mu^{*}\right), \\
& w_{\mu^{*}}^{*}>0>w_{\mu}^{*} \text {, } \\
& \ell^{*}=\ell^{*}\left(\mu, \mu^{*}\right), \\
& \ell_{\mu}^{*}, \ell_{\mu^{*}}^{*}<0 \text {. }
\end{aligned}
$$

\section{Optimal monetary policies and the noncooperative equilibrium}

The preceding discussion, which assumed money supply growth rates to be chosen arbitrarily, indicates that the level of real activity in the world economy is maximized if both countries adopt Friedman's (1969) rule by setting their money growth rates so that the nominal interest rate on bonds denominated in their own currency is zero. From $\langle 13\rangle$ this requires that $\mu=\mu^{*}=1 /(1+r)$. However, in an interdependent world economy such an outcome seems unlikely: if either country thinks the other country will adopt Friedman's rule, it will be in their own national interest to deviate from Friedman's rule by choosing a money growth rate greater than $1 /(1+r)$ because by doing so they can increase their welfare by changing the wage ratio, the double-factoral terms of trade, in their 
favor. This section of the paper assumes that governments act noncooperatively and choose money supply growth rates in order to maximize the utility of their country's representative consumer given the other country's money supply growth rate. First the policy problem for each individual country is examined and then the Nash equilibrium is determined.

Consider the policy problem facing the home country government. Their aim, given foreign policy, is to choose a time profile for the domestic money supply growth rate so as to maximize $\langle 3\rangle$ subject to the country's resource constraint and the equilibrium conditions $\langle 21\rangle$. Since the policy problem confronting both governments will look the same in every period, the world economy's equilibrium continues to be a steady state. Therefore, the home government's objective is to choose $\mu$ to maximize $U[c-g(\ell)]$ subject to $\langle 21\rangle$ and the economy's resource constraint which, since there is no initial debt, is

$$
c=w \ell \text {. }
$$

Substituting the constraints into the objective function, the government's problem is to

$$
\max _{\mu} U\left[w\left(\mu, \mu^{*}\right) \ell\left(\mu, \mu^{*}\right)-g\left(\ell\left(\mu, \mu^{*}\right)\right)\right] .
$$

The first-order condition for this problem is

$$
\ell w_{\mu}=\frac{-R}{1+R} \times w \ell_{\mu},
$$

where use has been made of the fact that consumer optimization implies $g^{\prime}(\ell)=w /(1+R)$. The government maximizes private sector utility by choosing the rate of growth of the money supply so that the marginal benefit of money growth, $\ell w_{\mu}$, equals the marginal cost of money growth, $-[R /(1+R)] w \ell_{\mu}$. The marginal benefit of money growth reflects the fact that increases in the money growth rate raise the domestic real wage by increasing the equilibrium wage ratio. This benefit is proportional to the amount of labor being supplied. The marginal cost of money growth arises because the equilibrium labor supply is below its socially optimal level due to the inflation tax distortion, $[R /(1+R]) w$. Increases in the rate of growth of the money supply reduce labor effort thus exacerbating the deadweight loss from the labor market distortion.

Assuming that the equilibrium real wage and employment functions are linear in the neighborhood of the initial equilibrium, given a foreign money supply growth rate of $\mu_{0}^{*}$, the optimal domestic money supply growth rate is determined by the intersection of the marginal benefit schedule, $M B\left(\mu, \mu^{*}\right) \equiv \ell w_{\mu}$, and the marginal cost schedule, $M C\left(\mu, \mu^{*}\right) \equiv-[R /(1+R)] w \ell_{\mu}$, at point $A$ in Figure 3 . Note that the marginal benefit of money growth is diminishing in $\mu$ since $\ell_{\mu}<0$ and the marginal cost of money growth is increasing in $\mu$ since $w_{\mu}>0$.

To see how the optimal domestic money supply growth rate depends on the rate of growth of the foreign money supply, totally differentiate the first-order condition $\langle 25\rangle$ to obtain

$$
\frac{d \mu}{d \mu^{*}}=\frac{-\left[\begin{array}{c}
R \\
1+R
\end{array} \times w_{\left.\mu^{*} \ell_{\mu}+\ell_{\mu^{*}} w_{\mu}\right]} \ell_{\mu}\left[w_{\mu}\left(1+\frac{R}{1+R}\right)+w \times \frac{d[R /(1+R)]}{d \mu}\right]\right.}{.}
$$




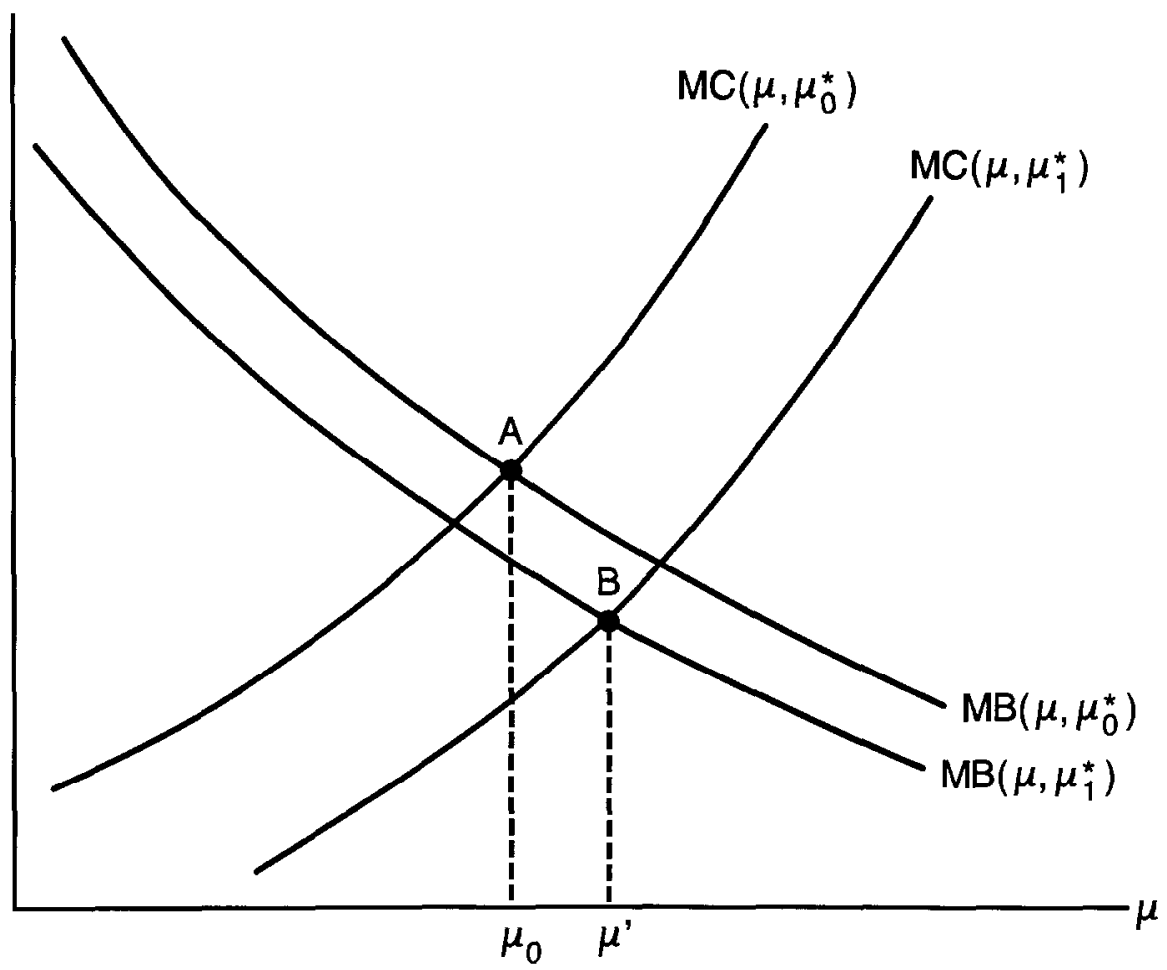

Figure 3.

Equation $\langle 26\rangle$ is the home country's reaction function which describes how the home country adjusts its monetary policy in response to changes in foreign monetary policy in order to satisfy the first-order condition for the government's problem equation $\langle 25\rangle$. The denominator of $\langle 26\rangle$ is clearly negative [note $\langle 13\rangle$ implies $d[R /(1+R)] / d \mu>0]$. However, the numerator can be positive or negative. If the term in parentheses in the numerator of $\langle 26\rangle$ is positive the numerator is negative and the home country's optimal response is to increase its money growth rate when the foreign country does so (i.e., $d \mu / d \mu^{*}>0$ ). Alternatively, if the term in parentheses in the numerator of $\langle 26\rangle$ is negative the numerator is positive and the home country's optimal response is to reduce its money growth rate when the rate of growth of the foreign money supply is increased.

The home country's optimal response to changes in the rate of growth of the foreign money supply thus depends on the sign of the term in parentheses in the numerator of $\langle 26\rangle$. In order to gain insight into the factors determining the sign of this term, note that since domestic money growth is chosen optimally $\langle 25\rangle$ can be used to help show that

$$
\frac{R}{1+R} \times w_{\mu^{*} \ell}+w_{\mu^{\prime}} \ell_{\mu^{*}}=w_{\mu^{\ell}}\left(\frac{\ell_{\mu^{*}}}{\ell}-\frac{w_{\mu^{*}}}{w}\right) .
$$

The term $\ell_{\mu^{*}} / \ell$ measures the proportional change in domestic employment in response to a change in the rate of growth of the foreign money supply. From the domestic labor supply function $\langle 11\rangle$, it is evident that $\ell_{\mu^{*}} / \ell=\eta \times\left(w_{\mu^{*}} / w\right)$. 
The preceding equality therefore can be rewritten as

$$
\frac{R}{1+R} \times w_{\mu^{*}} \ell_{\mu}+w_{\mu} \ell_{\mu^{*}}=w_{\mu} \ell \times\left(w_{\mu^{*}} / w\right) \times[\eta-1] \gtrless 0 \quad \text { as } \quad \eta \lessgtr 1,
$$

since $w_{\mu}>0>w_{\mu^{*}}$.

Together equations $\langle 26\rangle$ and $\langle 27\rangle$ imply that the key determinant of the optimal domestic monetary policy response to changes in foreign monetary policy is the elasticity of the home country's labor supply with respect to the after-tax real wage rate and that $d \mu / d \mu^{*} \gtrless 0$ as $\eta \lessgtr 1$. Intuitively, this result can be understood as follows. Suppose that $\eta<1$ and that initially the domestic money supply growth rate is optimally set at $\mu_{0}$ as shown by point $A$ in Figure 3. An increase in the rate of growth of the foreign money supply from $\mu_{0}^{*}$ to $\mu_{1}^{*}$ affects both the marginal benefit and the marginal cost of domestic money supply growth. By reducing home employment the increase in the foreign money growth rate lowers the marginal benefit of domestic money growth, $\ell w_{\mu}$, proportionally by $\ell_{\mu^{*}} / \ell=\eta \times\left(w_{\mu^{*}} / w\right)$. The increase in the foreign money growth rate also lowers the marginal cost of domestic money growth, $-[R /(1+R)] w \ell_{\mu}$, proportionally by $\mathrm{w}_{\mu^{*}} / w$ by lowering the domestic real wage. Since labor is supplied inelastically, i.e. $\eta<1$, at the initial optimum the marginal cost of domestic money growth falls by more than the marginal benefit. Therefore, the optimal home country response when $\eta<1$ is to increase its money supply growth

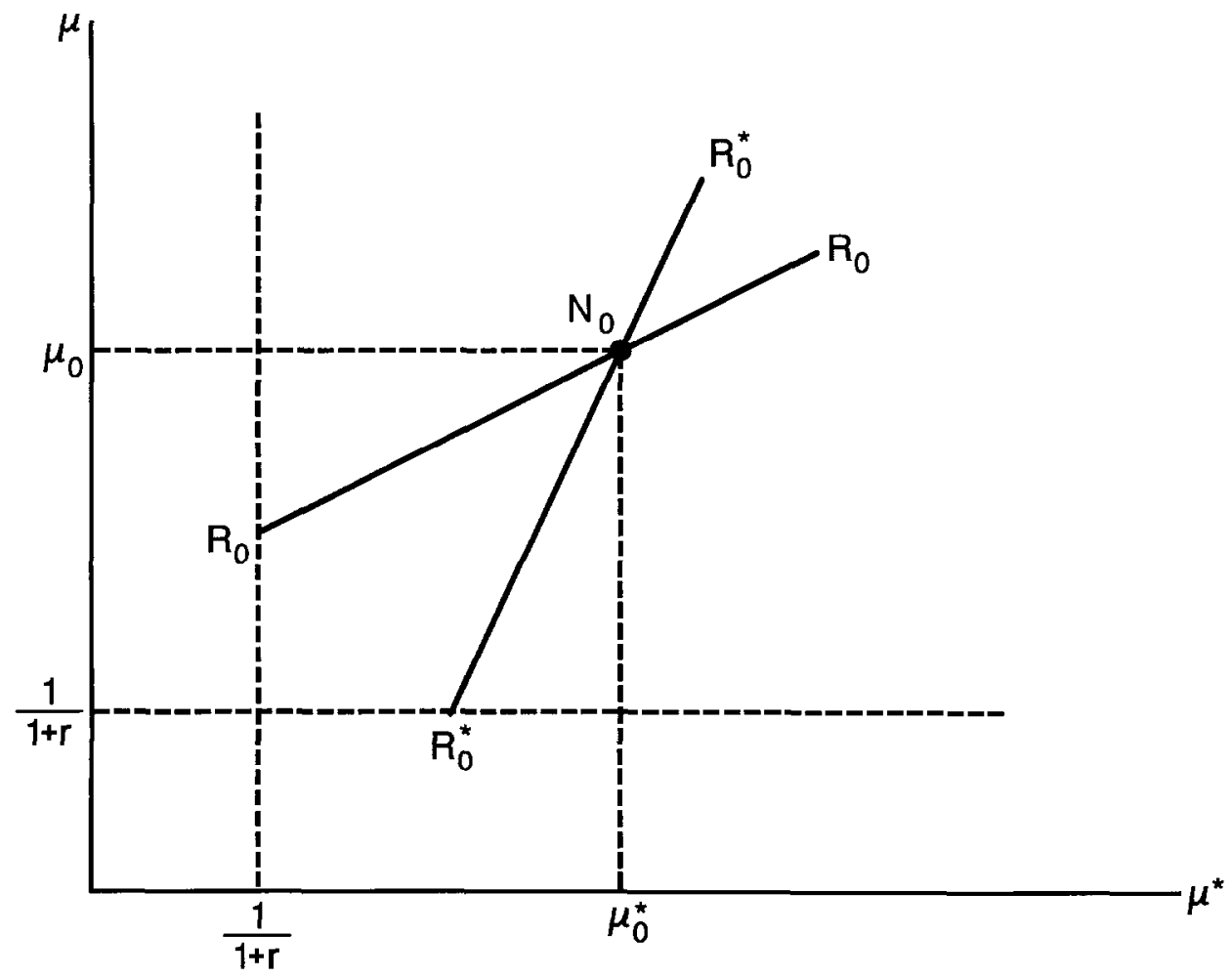

Figure 4. 
rate when the foreign country increases its money supply growth rate. This new situation is shown by the money growth rate $\mu^{\prime}$ coinciding with point $B$ in Figure 3. Similar reasoning explains why it is optimal for the home country to reduce its money supply growth rate in response to increases in the rate of growth of the foreign money supply when $\eta>1$.

By analogy with the home government's problem, the foreign government's problem is to

$$
\max _{\mu^{*}} U\left[w^{*}\left(\mu, \mu^{*}\right) \ell^{*}\left(\mu, \mu^{*}\right)-g\left(\ell^{*}\left(\mu, \mu^{*}\right)\right)\right] .
$$

The symmetry between the home and foreign policy problems means that the elasticity of the foreign country's labor supply with respect to the real wage is the key parameter determining how the foreign country's optimal money growth rate depends on the rate of growth of the home country's money supply. In fact, since the two countries have the same preferences if $\eta<1(\eta>1)$ both countries find it optimal to raise (reduce) their money growth rate when the other country's money growth rate increases.

The Nash equilibrium monetary policies must satisfy $\langle 24\rangle$ and $\langle 28\rangle$ simultaneously. The resulting equilibrium is depicted in Figures 4 and 5 . Figure 4 shows the case where $\eta<1$ and Figure 5 the case where $\eta>1$. The $R_{0} R_{0}$ schedule is the home country's reaction function as described implicitly by the first-order condition $\langle 25\rangle$. The foreign reaction function, which is determined by the

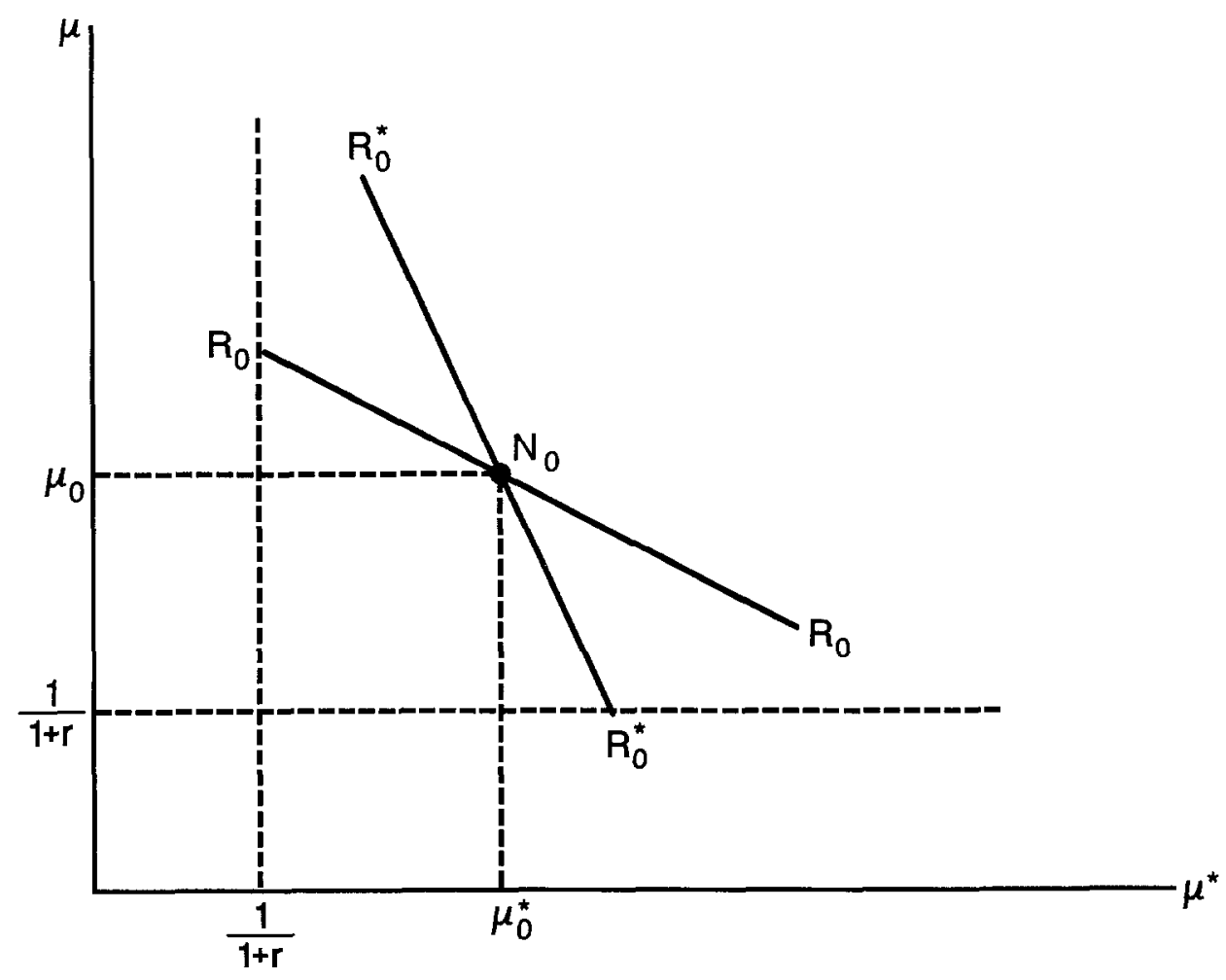

Figure 5. 
first-order condition for the foreign policy problem $\ell^{*} w_{\mu^{*}}^{*}=-\left[R^{*} /\left(1+R^{*}\right)\right] w^{*} \ell_{\mu^{*}}^{*}$, is depicted by the $R_{0}^{*} R_{0}^{*}$ schedule. In each figure the Nash equilibrium is at $N_{0}$ and the corresponding money growth rates are $\mu_{0}$ and $\mu_{0}^{*}$.

\section{Technological change and optimal monetary policies}

The previous section characterized the noncooperative Nash equilibrium monetary policies of the home and foreign countries given world economic conditions. In this section of the paper the focus is on how changes in world economic conditions affect monetary policy at home and abroad given that policies are set noncooperatively. The discussion focuses on the case where $\eta<1$ since empirical studies of labor supply generally imply that the response of hours worked to changes in the wage rate is small (see Killingsworth, 1983). The results for the case where $\eta>1$ are mentioned in the Notes. Here the effects of technological change on optimal monetary policies are explored.

\section{V.A. Technological change for given monetary policies}

Suppose that the home country experiences a technological improvement that alters its required labor input for all goods by $\hat{a}<0$. As shown in Figure 6 , a technological improvement of this sort shifts the $A(z)$ schedule, which captures

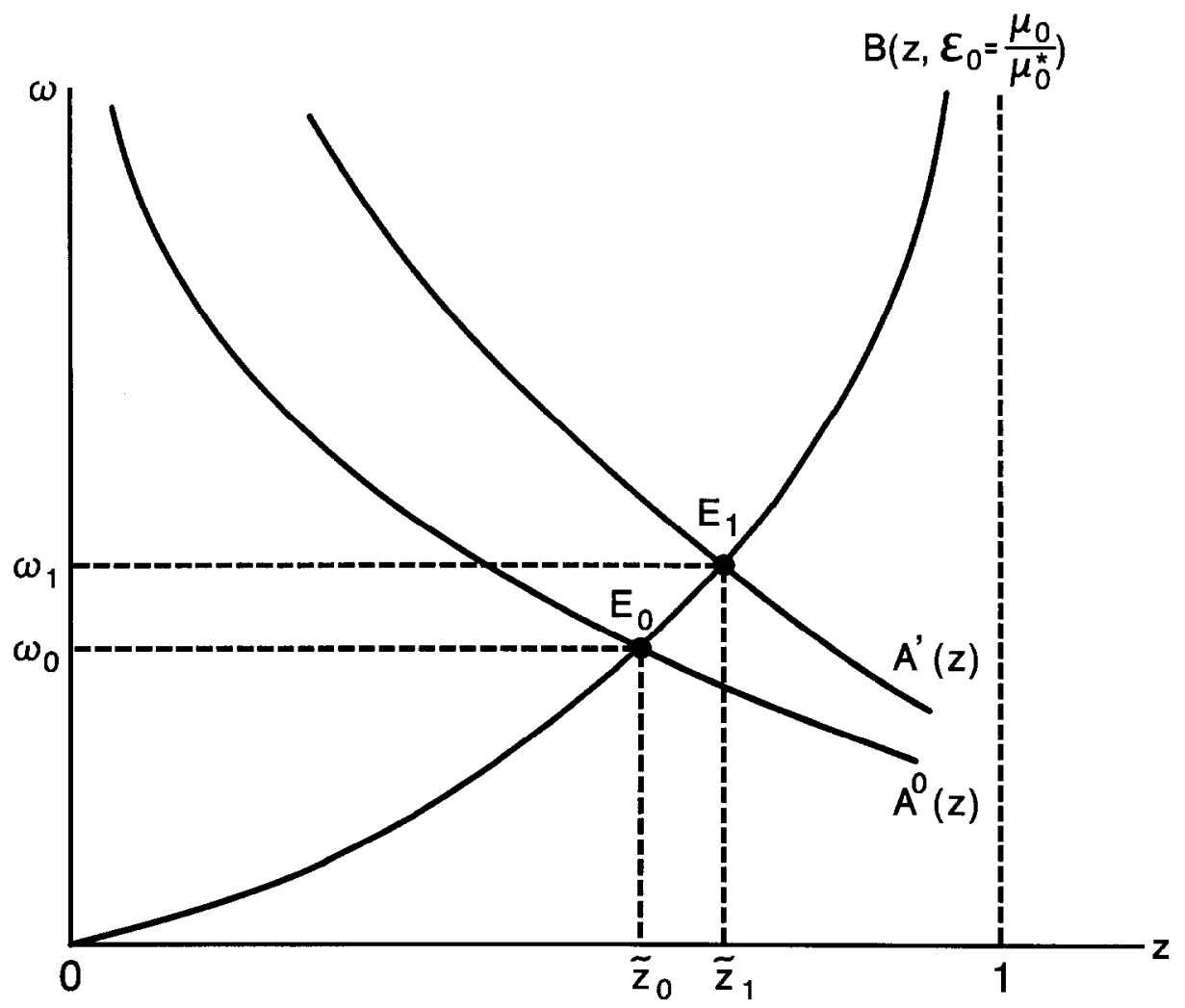

Figure 6. 
the relative efficiency of the two countries in producing goods, up proportionally by $-\hat{a}$ from $A^{0}(z)$ to $A^{\prime}(z)$. Given the initial equilibrium monetary policies, $\mu_{0}$ and $\mu_{0}^{*}$, the increased productivity of domestic labor gives the home country a comparative advantage in a broader range of goods (the marginal good increases from $\tilde{z}_{0}$ to $\tilde{z}_{1}$ ) and improves the wage ratio from the home country's perspective from $\omega_{0}$ to $\omega_{1}$. Formally it can be shown from $\langle 16\rangle$ and $\langle 17\rangle$ that $\tilde{z}=-\left[\tilde{z} / \omega\left(B_{z}-A_{z}\right)\right] \times \hat{a}>0$ and $0<\hat{w}=-\left[B_{z} /\left(B_{z}-A_{z}\right)\right] \times \hat{a}<|\hat{a}|$.

Since goods in the range $\left[0, \tilde{z}_{0}\right]$ are produced by the home country both before and after the technological improvement, their prices are determined by the condition $P_{t}(z)=W_{t} a(z)$ so that at the time the change in technology occurs $\hat{P}(z)=\hat{W}+\hat{a}$ for $z \in\left[0, \tilde{z}_{0}\right]$. Goods in the range $\left[\tilde{z}_{1}, 1\right]$ are produced by the foreign country before and after the technological change and hence their prices satisfy $P_{t}(z)=e_{t} W_{t}^{*} a^{*}(z)=W_{t}(1 / \omega) a^{*}(z)$. Therefore, $\hat{P}(z)=\hat{W}-\hat{\omega}$ for $z \in\left[\tilde{z}_{1}, 1\right]$. The location of production changes from the foreign country to the home country for goods in the interval $\left[\tilde{z}_{0}, \tilde{z}_{1}\right]$. Using the same type of reasoning that established the effects of arbitrary changes in monetary policy on the prices of goods whose location of production changes, it can be shown that $\hat{P}(z)=\hat{W}+\hat{a}+\hat{D}(z)$ for $z \in\left[\tilde{z}_{0}, \tilde{z}_{1}\right]$, where $0 \leqslant \hat{D}(z)<|\hat{a}|, \partial \hat{D}(z) / \partial z>0, \hat{D}\left(\tilde{z}_{0}\right)=0$, and $\hat{D}\left(\tilde{z}_{1}\right)=-\hat{\omega}-\hat{a}>0$.

Using these expressions and the fact that $\hat{P}=\int b(z) \hat{P}(z) d z$, it follows that given the initial monetary policies the change in the home country real wage, $\hat{w}=\hat{W}-\hat{P}$, is

$$
\hat{w}=-\theta\left(\tilde{z}_{0}\right) \hat{a}-\int_{\tilde{z}_{0}}^{z_{1}} b(z)[\hat{a}+\hat{D}(z)] d z+\left[1-\theta\left(\tilde{z}_{1}\right)\right] \hat{\omega}>0 .
$$

where the sign follows from the facts that $\hat{a}<0$ and $0 \leqslant \hat{D}(z)<|\hat{a}|$.

The home country real wage thus rises in response to an improvement in home technology. Intuitively, the home real wage must rise because, as highlighted by $\langle 29\rangle$, the home real wage increases in terms of all goods. Real wages rise in terms of goods in the interval $\left[0, \tilde{z}_{0}\right]$, which are produced at home before and after the technological improvement, because of the increased efficiency of production. This effect is captured by the first term on the right-hand side of $\langle 29\rangle$. Real wages rise in terms of goods in the interval $\left[\tilde{z}_{1}, 1\right]$, which are produced abroad before and after the technological improvement, because of the rise in the wage ratio. The last term in $\langle 29\rangle$ shows this effect. Real wages also rise for goods in the interval $\left[\tilde{z}_{0}, \tilde{z}_{1}\right]$ as reflected by the middle term in $\langle 29\rangle$. These goods are produced abroad initially but in the home country after the change in technology. Two factors influence the real wage in terms of these goods. First, the increased efficiency of home production raises the real wage in terms of these goods as captured by the $\hat{a}$ appearing inside the brackets. Second, the location of production switches from the foreign country to the home country. Since the home wage rises relative to the foreign wage, i.e. $\hat{\omega}>0$, this works to dampen the increase in the real wage in terms of goods in the range $\left[\tilde{z}_{0}, \tilde{z}_{1}\right]$. However, the shift in the location of production of these goods must be beneficial, otherwise it would not occur.

Similar reasoning shows that the change in the foreign real wage is given by

$$
\hat{w}^{*}=-\theta\left(\tilde{z}_{0}\right)(\hat{a}+\hat{\omega})-\int_{\tilde{z}_{0}}^{\tilde{z}_{1}} b(z)[\hat{a}+\hat{D}(z)+\hat{\omega}] d z>0,
$$


where use has been made of the facts that $\hat{\omega}<|\hat{a}|$ and $\hat{a}+\hat{D}(z)+\hat{\omega}$ reaches a maximum of zero at $\tilde{z}_{1}$ which follows from the properties of the $\hat{D}(z)$ function.

Once again, since trade in goods is a substitute for labor mobility after-tax wages move in the same direction in both countries. However, and this result is crucial for what follows, although real wages rise in both countries, the real wage rises by more in the home country where the technological improvement occurs. ${ }^{4}$

\section{V.B. Changes in optimal monetary policies}

The results just derived hold for any given monetary policies. However, since monetary policies are being set optimally in a noncooperative fashion, both countries will adjust their money growth rates in response to changes in world economic conditions. When these policy changes are taken into account there will be other effects on real wages and the international pattern of specialization to be considered. Nonetheless, the results that were just derived are useful for establishing the effects of the home country's improved technology on the Nash equilibrium because they determine how the marginal cost and benefit of money growth, and hence the home and foreign reaction functions, are altered.

To see this, consider the situation of the home country depicted in Figure 7. Initially, the home country's optimal policy is to set its money growth rate at $\mu_{0}$ as determined by point $A$ where the marginal benefit of money growth, $\ell w_{\mu}$, equals the marginal cost of money growth, $-[R /(1+R)] w \ell_{\mu}$. As was just

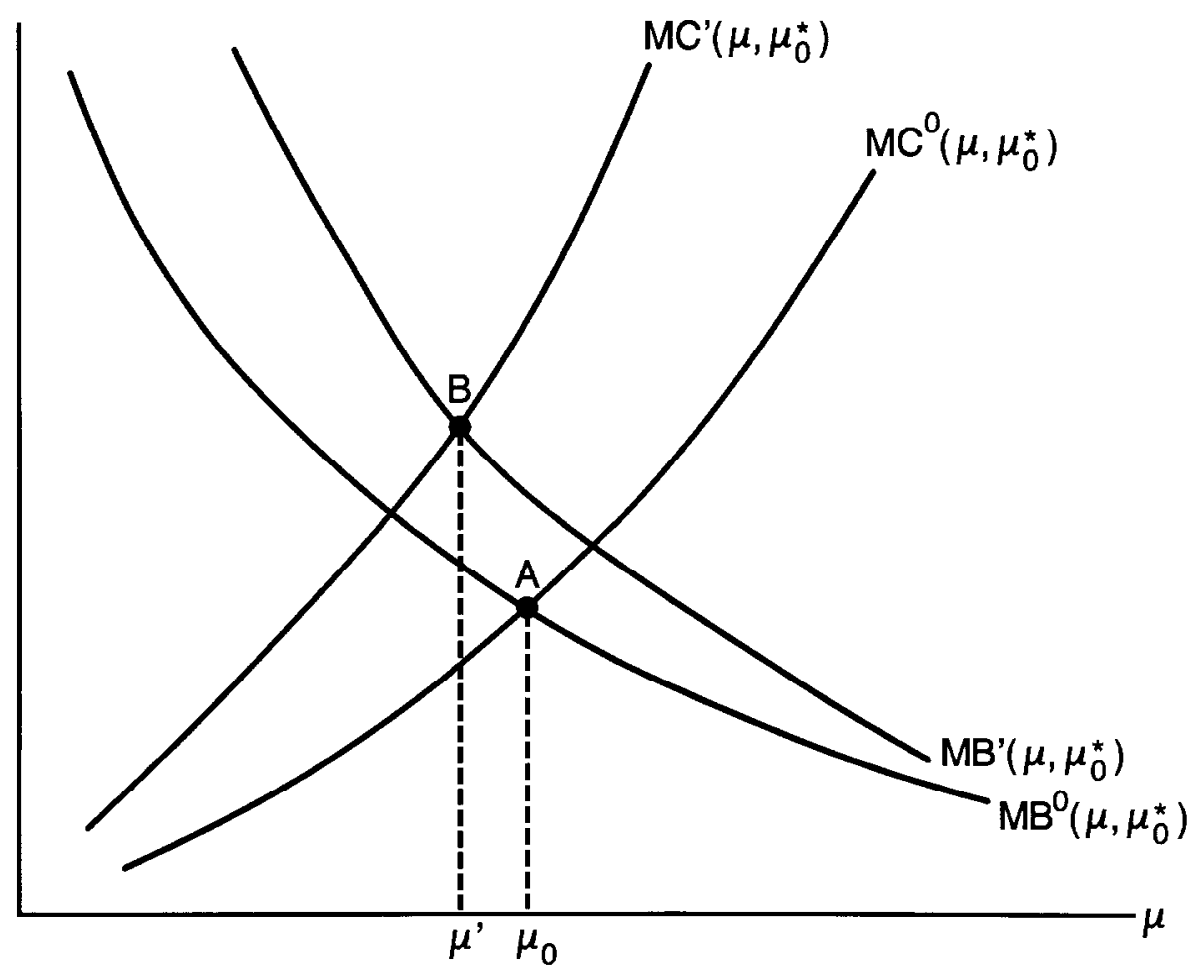

Figitra 7 
established, a technological improvement in the home country raises the home real wage for any given combination of home and foreign monetary policies. The increase in the real wage raises the marginal cost of money growth as shown by the upward shift of the marginal cost curve in Figure 7. In addition, it follows from the labor supply function $\langle 11\rangle$ that the technological improvement increases the domestic labor supply by $\hat{\ell}=\eta \hat{w}$, where $\hat{w}$ is given by $\langle 29\rangle$. This raises the marginal benefit of money growth. However, since $\eta<1$ the marginal cost of money growth rises by proportionately more than the marginal benefit as shown in the figure. Therefore, given the rate of growth of the foreign money supply, the improvement in the home country's technology lowers the optimal rate of growth of the money supply from $\mu_{0}$ to $\mu^{\prime}$ as shown by point $B$ in Figure 7 .

It has now been established that when there is a technological improvement in the home country and $\eta<1$ the home country's optimal money supply growth rate falls for any given foreign money supply growth rate. This is shown in Figure 8 where the initial Nash equilibrium is at $N_{0}$ with money supply growth rates at home and abroad optimally set at $\mu_{0}$ and $\mu_{0}^{*}$. As highlighted by the $45^{\circ}$ line, the initial equilibrium is assumed to be symmetric in the sense that $\mu_{0}=\mu_{0}^{*}$. The technological improvement in the home country shifts the home reaction function from $R_{0} R_{0}$ down to $R_{1} R_{1}$. Similar reasoning also implies that the foreign reaction function shifts in to the left as a result of the technological

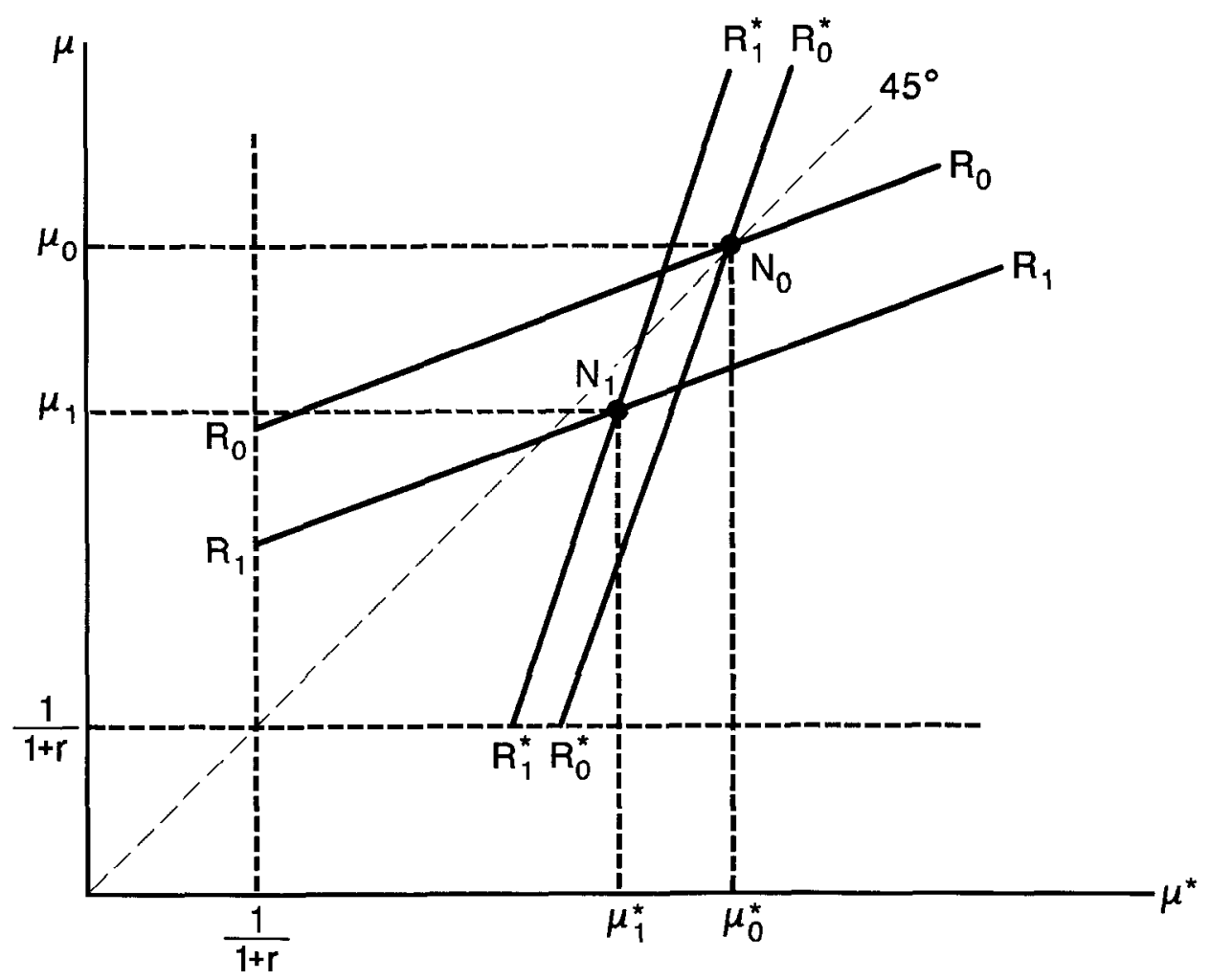

Figure 8 . 
improvement at home since the foreign real wage, like the home rcal wage, increases for any given combination of home and foreign money growth rates. However, since the home real wage rises by a greater percentage than the foreign real wage, i.e., since $\hat{w}>\hat{w}^{*}$, the home reaction shifts by relatively more than the foreign reaction function.

The new Nash equilibrium is at $N_{1}$ with money growth rates $\mu_{1}$ and $\mu_{1}^{*}$. As can be seen, the technological improvement in the home country lowers equilibrium money growth rates in both countries. As a consequence, equilibrium inflation rates fall in both countries. Note that this fall in inflation rates is a result solely of the endogenous policy response on the part of the two countries. A one time change in technology like that being considered here does not alter the rate of growth of output and hence without the induced change in money supply growth rates would not influence inflation rates which, in general, reflect the difference between money growth rates and output growth rates. The fall in money growth rates and inflation reflects the fact that, since $\eta<1$, the technological improvement increases the marginal cost of the distortions associated with money growth by more than it raises the marginal benefit of money growth arising from its impact on real wages.

In addition, note that while money growth rates in both countries fall as a result of the technological improvement in the home country, the home country's money growth rate declines by proportionately more than the foreign country's money growth rate. That is $\mu / \mu^{*}$ falls. This means that the rate of depreciation of the home currency also falls since $\varepsilon=\mu / \mu^{*}$. Once again, these results concerning the relative change in money growth rates reflect the fact that governments are optimally adjusting their monetary policics to changing world economic conditions and would be absent without such an endogenous policy response. ${ }^{5}$

These results are appealing because they are consistent with the observation that developing countries generally have higher money growth rates and higher inflation rates than do industrialized countries. This fact is illustrated by the data in Table 1. For instance, from 1982-89 the average annual rate of inflation for the ind ustrialized countries was 4.3 per cent and the average rate of money growth for the major industrialized countries was 8.5 per cent. Over this same period the average inflation ratc for developing countries was 48.1 per cent and the average rate of money growth was 53.2 per cent. In addition, the results also imply that the money growth rates of all nations are influenced by technology levels in both industrialized and developing countries. The higher technology levels of industrialized countries simply make money growth and inflation relatively more costly for industrialized countries than for developing countries. Hence they tend to have lower money growth and inflation rates despite the fact that, according to the model, the higher technology levels of industrialized countries actually help keep down the money growth rates and inflation rates of developing countries.

A traditional explanation of higher money growth and inflation rates in developing countries has to do with international differences in the collection costs associated with fiscal taxes such as a wage tax or an income tax. It is generally argued that these collection costs are relatively higher in developing countries than in industrialized countries. Therefore, given identical revenue needs, optimal taxation for revenue purposes argues that developing countries should rely more heavily on the inflation tax than industrialized countries and, 
TABLE 1. Average annual money growth rates and inflation rates in industrialized and developing countries.

\begin{tabular}{|c|c|c|c|c|}
\hline \multirow{3}{*}{$1972-1981$ average } & \multicolumn{2}{|c|}{ Industrialized countries } & \multicolumn{2}{|c|}{ Developing countries } \\
\hline & \multicolumn{2}{|c|}{$\begin{array}{l}\text { Money growth Inflation } \\
\text { (percentage) }\end{array}$} & \multicolumn{2}{|c|}{$\begin{array}{l}\text { Money growth miration } \\
\text { (percentage) }\end{array}$} \\
\hline & & 9.2 & & 22.7 \\
\hline 1982 & 9.7 & 7.5 & 32.6 & 25.3 \\
\hline 1983 & 10.5 & 5.0 & 37.9 & 32.7 \\
\hline 1984 & 8.3 & 4.8 & 48.9 & 38.6 \\
\hline 1985 & 8.8 & 4.1 & 45.9 & 40.4 \\
\hline 1986 & 9.1 & 2.4 & 35.3 & 31.5 \\
\hline 1987 & 6.7 & 3.0 & 50.5 & 41.4 \\
\hline 1988 & 7.4 & 3.3 & 77.4 & 70.5 \\
\hline 1989 & 7.8 & 4.4 & 96.8 & 104.1 \\
\hline
\end{tabular}

Notes: The source for this data is World Economic Outlook, International Monetary Fund, Washington, D.C., May 1990. Inflation rates are for consumer prices and money growth rates are for broad money, essentially M2. The money growth rates for the industrialized countries are for the major industrialized countries as defined by the IMF.

as a consequence, should have higher money growth and inflation rates. The model outlined here is capable of producing such results. International differences in tax collection costs thus complement international differences in technology levels as an explanation of international differences in money growth and inflation rates.

\section{Conclusion}

Several extensions of the current framework readily suggest themselves. First, equilibrium fiscal policies could be determined along with equilibrium monetary policies. Second, the effects of changes in world economic conditions on equilibrium policies can be explored assuming policies are set cooperatively. Whether the assumption of cooperative or noncooperative behavior is a better maintained hypothesis is an empirical question. Third, the implications of policy interdependence in a growing world economy can be studied. Growth due to either exogenous technological change or endogenous growth could be added to the model. Finally, a multi-country version of the model could be developed and used to answer questions such as what sorts of changes in world economic conditions are likely to encourage events such as European monetary integration or the effects of country size on optimal policies in an interdependent world economy.

\section{Notes}

1. Canzoneri and Gray (1985) and Oudiz and Sachs (1985) both consider how changes in world economic conditions alter equilibrium policies. However, unlike the setup adopted here, these models are not grounded in utility maximizing behavior and the government's objective function is $a d$ hoc and not clearly related to private sector welfare. 
2. For example, it is shown that a technological improvement in one country alters not only the absolute money growth rates in the two countries but also alters relative money growth rates. In a two good Ricardian model relative money growth rates are not affected by technological change. Therefore, without allowing for adjustment at the extensive margin the Ricardian model is unable to shed light on the conditions that contribute to observed differences in money growth rates and inflation rates across countries.

3. With this specification of within-period preferences the consumer's maximization problem can be solved in two stages, a tractable measure of real consumption is readily defined, and there is no wealth effect on labor supply. This allows attention to be directed toward the substitution effects of inflation in its role as a tax.

4. In a two good version of the model with variable labor supply and Cobb-Douglas preferences over goods, it can be shown that $w=\hat{w}^{*}$. Adjustment at the extensive as well as the intensive margin is thus central to the results that follow. Recall Note 2.

5. When $\eta>1$ the home and foreign reaction functions shown in Figure 5 shift up and to the right. In the new equilibrium the home country's money growth rate must rise but the foreign money growth rate may be higher or lower than it was before. However, $\mu / \mu^{*}$ must rise so $\hat{\mu}>\hat{\mu}^{*}$ must hold.

\section{References}

Aschauer, David, and Jeremy Greenwood, 'A Further Exploration in the Theory of Exchange Rate Determination,' Journal of Political Economy, October 1983,91:868-875.

Canzoneri, Matthew B., And Jo Anna Gray, 'Monetary Policy Games and the Consequences of Non-Cooperative Behavior,' International Economic Review, October 1985, 26: $547-564$.

Chari, V.V., and Patrick J. Kehoe, 'International Coordination of Fiscal Policy in Limiting Economies,' Journal of Political Economy, June 1990, 98: 617-636.

Devereux, Michael B., 'International Cooperation, Precommitment, and Welfare,' International Economic Review, May 1990, 31: 439-456.

Dornbusch, Rudiger, Stanley Fischer, and Paul A. Samuelson, 'Comparative Advantage, Trade, and Payments in a Ricardian Model with a Continuum of Goods,' American Economic Review, December 1977, 67: 823-839.

Eichengreen, Barky, 'International Policy Coordination in Historical Perspective: A view from the Interwar Years,' in Willem H. Buiter and Richard C. Marston, eds., International Policy Coordination, Cambridge: Cambridge University Press, 1985.

Friedman, Milton, 'The Optimum Quantity of Money,' in his The Optimum Quantity' of Money and Other Essays, Chicago: Aldine, 1969.

Hamada, KoICHI, 'A Strategic Analysis of Monetary Interdependence,' Journal of Political Economy, August 1976, 84: 677-700.

Hamada, KoIchi, 'Macroeconomic Strategy and Coordination under Alternative Exchange Rates,' in Rudiger Dornbusch and Jacob A. Frenkel, eds., International Economic Policy: Theory and Evidence, Baltimore: Johns Hopkins, 1979.

Hamada, KoICHI, The Political Economy of International Monetary Interdependence, Cambridge: MIT Press, 1985.

Helpman, Elhanan, 'An Exploration in the Theory of Exchange-Rate Regimes,' Journal of Political Economy, October 1981, 89: 865-890.

Kehoe, Patrick J., 'Coordination of Fiscal Policies in a World Economy,' Journal of Monetary' Economics, May 1987, 19: 349-376.

Kehoe, Patrick J., 'Policy Cooperation among Benevolent Governments may be Undesirable,' Review of Economic Studies, April 1989, 56: 289-296.

Killingsworth, Mark R., Labor Supply, Cambridge: Cambridge University Press, 1983.

Kimbrough, Kent P., 'The Optimum Quantity of Money Rule in the Theory of Public Finance,' Journal of Monetary Economics, November 1986, 18: 277-284.

Kimbrough, Kent P., 'Specialization, the Terms of Trade, and the International Transmission of Monetary Policy,' unpublished manuscript, Duke University, 1989. Forthcoming in Canadian Journal of Economics.

Kimbrough, Kent P., 'Optimal Taxation and Inflation in an Open Economy, Journal of Economics, Dynamics, and Control, January 1991, 15: 179-196. 
Oudiz, Gilles, AND Jefrerey Sachs, 'International Policy Coordination in Dynamic Macroeconomic Models,' in Willem H. Buiter and Richard C. Marston, eds., International Economic Policy Coordination, Cambridge: Cambridge University Press, 1985.

Rogoff, Kenneth, 'Can International Monetary Policy Cooperation be Counter-productive, Journal of International Economics, May 1985, 18: 199-217.

Stockman, Alan C., 'Effects of Inflation on the Pattern of International Trade,' Canadian Journal of Economics, August 1985, 18: 587-601.

Turnovsky, StePhen J., 'The Gains from Fiscal Cooperation in the Two-Commodity Real Trade Model,' Journal of International Economics, August 1988, 25: 111-127. 